\title{
Impact Assessment of Indigenous Field-Level Water Storage Structure (Diggi) on Agriculture in the Great Indian Desert
}

\section{Pratap Chandra Moharana ( $\sim$ Pratap.Maharana@icar.gov.in )}

Central Arid Zone Research Institute https://orcid.org/0000-0001-6625-5784

\section{R.K. Goyal}

Central Arid Zone Research Institute

Deepesh Machiwal

Central Arid Zone Research Institute

C.B. Pandey

Central Arid Zone Research Institute

\section{Research Article}

Keywords: Diggi, Micro-farm water storage structures, Indigenous system, Irrigated agriculture, Remote sensing and geographic information system, western Rajasthan

Posted Date: August 3rd, 2021

DOl: https://doi.org/10.21203/rs.3.rs-750834/v1

License: (9) This work is licensed under a Creative Commons Attribution 4.0 International License. Read Full License 


\title{
Impact Assessment of Indigenous Field-Level Water Storage Structure (Diggi) on Agriculture in the Great Indian Desert
}

\author{
P.C. Moharana ${ }^{1}$, R.K. Goyal, Deepesh Machiwal, C.B. Pandey \\ Division of Natural Resources, ICAR-Central Arid Zone Research Institute, Jodhpur-342003, \\ Rajasthan, India \\ ${ }^{1}$ Corresponding Author: Pratap.Maharana@icar.gov.in
}

\begin{abstract}
In the arid region of Rajasthan, India, it is very often a challenge to store rain/surface water for yearround use by human and livestock. The inhabitants of this desert area have developed several water storage structures, which they used to construct based on their indigenous knowledge of local terrain conditions. Recently, farmers living in the lower command areas of Indira Gandhi canal have constructed micro-farm water storage structures, called diggi, in their cropland. They store allocated canal water in diggi to timely utilize it as per irrigation requirements, and thus, done away with problems of deficit and untimely canal water supply. This impact assessment study, carried out in Poogal tehsil of Bikaner district, analyzed high-resolution satellite images of two years and used geographic information system to quantify diggi structures and studied the diggi-growth interactions with changing rainfall pattern as well as land use/land cover. Results showed that during 2018, about 3243 number of structures were constructed compared to 241 existed during 2004-05. The mean annual rainfall increased by $30 \%$ and crop area by 12772 ha during the same period that included $7.86 \%$ increase in irrigated and $2.98 \%$ in rainfed croplands. Thus, diggi based water management has been immensely helpful in the perspective of irrigated agriculture in the desert region.
\end{abstract}

Keywords: Diggi, Micro-farm water storage structures, Indigenous system, Irrigated agriculture, Remote sensing and geographic information system, western Rajasthan

\section{INTRODUCTION}

As we move into the next millennium, the biggest and fundamental concern for the society will be on how the people manage the available water. As per estimates made by various world water forums, by the year 2030, one-third of world's population will feel the heat of water scarcity and majority of such population (about 2.1 billion) will be from world's dryland region (UNESCO, UN-Water, 2020). India has about 31.7 million ha (m ha) land under hot arid zone and a major proportion of such land (62\% or $19.6 \mathrm{~m}$ ha) lies in the Great Indian Desert region situated in Rajasthan. The arid region of Rajasthan, which is bounded by aridity index values between -59.5 in the east (in Sikar district) and -88.9 in the west (in Jaisalmer district) comprises twelve districts (Ram, 2014). There is a wide spatial variability in the rainfall distribution that influences the availability of water resources. This is primarily due to low (100-600 $\mathrm{mm} \mathrm{yr}^{-1}$ ) and erratic rainfall (coefficient of variation ranging from 20$65 \%)$ coupled with high potential evapotranspiration $\left(\sim 2000 \mathrm{~mm} \mathrm{yr}^{-1}\right)$. The annual rainfall is the lowest $(100-150 \mathrm{~mm})$ in the west and the highest $(500-600 \mathrm{~mm})$ in the east that helps about $75 \%$ of desert dwellers to continue agriculture at least once in a year. With scarce and unreliable rainfall situation, status of groundwater and surface water is non-uniform and 
highly variable in space and time. With a long-term average annual rainfall of $317 \mathrm{~mm}$, the total annual estimated groundwater availability in western Rajasthan would be $3351 \mathrm{Mm}^{3}$ as against total annual water demand (draft) of $7790 \mathrm{Mm}^{3}$ in the year 2020 with $221 \%$ stage of groundwater development (Goyal et al., 2009). However, people extract the groundwater indiscriminately through dug wells and tube wells and use for drinking and agricultural purposes. Due to over-extraction, groundwater levels have been fast-depleting in 9 of total 12 arid districts of Rajasthan, and Bikaner is one of those districts. Surface water in Bikaner district is handicapped as there is hardly any major river and as such freshwater received during rains is stored in various forms of natural and man-made structures. Thus, common people of this region struggle hard to collect water, conserve it and use it efficiently for various purposes. Such activities are very important for desert area, as (i) this region is too dry for conventional rainfed agriculture, (ii) it is home to about 27 million of people, and (iii) it is a region where demand for water is going to increase because of sprawling demands from agriculture, industry and service (tourism) sectors. Therefore, people of this region always think about alternate ways and means of managing the available surface water.

Management of surface water is one of the daunting tasks for people living in western Rajasthan as per requirement of growing human (27.09 million, 2011 census) and livestock populations $\quad\left(27.6\right.$ million, 2019, 20 $0^{\text {th }}$ livestock census, Source: http://animalhusbandry.rajasthan.gov.in/livestock_census.aspx). Therefore, local people of this region have constructed a number of traditional as well as improved surface water harvesting structures like tanka, kund, nadi (village ponds), khadin (a runoff harvesting system) and baoli (Khan and Narain, 2000). A tank, locally called as tanka, is a manmade structure for individual household and also serves the community having higher storage capacity ranging from 5000 to 600,000 litres of water. A tank of 21000 litres capacity is found sufficient to meet drinking water requirement of a family with 6 persons for round the year (Goyal et al., 2008). A baoli is regarded as a community well as such wells were built by banjara or mobile trading people for drinking water in Rajasthan (Hussain et al., 2014). The nadi or village pond is a common rainwater harvesting structure representing one of the oldest practices in desert area. Such structures are utilized by about $42 \%$ of population in arid zone of Rajasthan. These ponds store runoff water from adjoining natural catchments during the rainy season. Most of nadis have a capacity of 1,200 to $15,000 \mathrm{~m}^{3}$ and stores water for a period ranging from 2 to 8 months in a year. Khadin is a unique system of water harvesting, moisture conservation and utilization. Alone in Jaisalmer district, there are more than 500 khadins (Goyal et al., 2018). The main feature of khadin is a very long (100-300 m) earthen embankment built across the lower hill slopes lying below gravelly uplands. This system has the dual benefits of harvesting rainwater on farmland and subsequent use of this watersaturated land for crop production. The water holding capacity of khadin soil ranges from 200 to $250 \mathrm{~mm} \mathrm{~m}^{-1}$ depth (CAZRI, 2009). Reservoirs are another common form of water storage structures in higher rainfall zones mainly in the east adjoining to Aravalli hills, which receive more than $350 \mathrm{~mm}$ average annual rainfall. The Jaswant Sagar dam built on the Luni River near Bilara, Sardar Samand dam on the Guhiya River to the north of Pali, the Hemawas dam 
on the Bandi River at Pali, the Bankli Talav on the Sukri River near Bhadrajun and the Jawai dam built across Jawai River are historically important and are still relevant for region's agriculture and drinking water. Besides, this part of state also gets benefit of two big canal projects, IGNP (Indira Gandhi Nahar Pariyojana) and NCP (Narmada Canal Project). The IGNP is a large surface water transfer project constructed during 1960s in the heart of desert area with an objective of using this water to transform the extensive sandy wasteland of western part of Rajasthan into greenery. Within Rajasthan, the canal is $445 \mathrm{~km}$ long passing through the sand dune covered terrain in 7 of 12 arid districts. The IGNP Stage-I is restricted to Sriganganagar, Churu, Bikaner and Hanumangarh districts and the Stage-II to Jaisalmer and Barmer districts. The entire project area serves a vast Culturable Command Area (CCA) of 19.63 lakh ha land of the region (Sharma et al., 2010; Shrivastava et al., 2013). The NCP caters to the needs of people of Barmer and Jalor districts.

Recently, Diggi has been added as another water storage structure by farming community in the IGNP command area in western Rajasthan. In India, farm pond structures similar to diggi in Rajasthan are very common in the eastern region where normal annual rainfall is much higher than Rajasthan. The 50-year (1951-2000) normal annual rainfall varies from 500-1000 $\mathrm{mm}$ in Andhra Pradesh and Telengana, and 1001-2000 mm in West Bengal, Odisa, Bihar and Jharkhand states (https://mausam.imd.gov.in/imd_latest/contents/rainfall information.php\#). There have been reports (Kumar et al., 2016; Outcome Story_ICRISAT_Farm ponds.pdf (cgiar.org) of positive impacts of such structures on fisheries and livestock rearing, crop diversification and improvement in water availability. The basic objective of farm pond structure is one way to deal with water scarcity. In Rajasthan, even under arid climate, low and erratic rainfall and poor water resources conditions, farmers have started constructing such structures in a large number in canal command area. Over a period of time, there has been a situation of water scarcity and uncertainty in the timely supply of IGNP canal water that creates problems in the tail end of CCA. Under such conditions, famers of region have evolved a new way to conserve and manage canal water in their farm ponds called diggi. A field photograph of diggi structure is shown in Fig. 1.

During a semi-detailed survey of this area (2004-2018), it was found that such structures have been increased to a large extent. This study has been undertaken with three objectives: (i) to quantify the spatial distribution of diggi structures, (ii) to explore changes in rainfall patterns, and (iii) to understand whether such indigenous field-water management systems have any impact on the growing irrigated agriculture of the region.

\section{STUDY AREA AND DATA DESCRIPTION}

This study was carried out in Poogal tehsil of Bikaner district in Rajasthan, India (Fig. 2). As per 2011 census, Poogal tehsil has a geographical area of $2616.23 \mathrm{~km}^{2}$. The tehsil is located within the desert area of the district where $58 \%$ of the area is covered by sand dunes and $33 \%$ area by sandy plains (Moharana et al., 2013). The western, southwest, northern and northeast 
parts of the district are largely covered with 12 to $20 \mathrm{~m}$ high sand dunes. The district receives a scanty annual rainfall that varies from $300 \mathrm{~mm}$ (in the east) to $180 \mathrm{~mm}$ (in the west). The surface water resources of the district are rather meager, due to erratic and low rainfall, large infiltration rate of the upper sediments and practically having no river system. Under such situation, the segment of IGNP (Indira Gandhi Nahar Pariyojana) passing through the district is the lifeline for people, livestock and agriculture. As per district agricultural statistics of 2016-17, out of total 1.59 mha cultivated area in Bikaner, 0.46 million ha area was net total irrigated. The IGNP canal contributes to 0.20 mha or $44.51 \%$ of total net irrigated area and rest (55.49\% area) is irrigated through dug wells and tube wells. Between 2006-07 and 201617, total sown area during kharif season (July to October) has increased from $1.31 \mathrm{mha}$ to 2.07 mha. During rabi period (October to March), total sown area has increased from 0.28 mha (2006-07) to $0.50 \mathrm{mha}$ in 2015-16 (http://www.agriculture.rajasthan.gov.in/). Poogal tehsil is dominantly a rural town, and the major occupation of the local people is overwhelmingly agriculture (in $\sim 90 \%$ area). As per the 2011 census, the study area is inhabited by 67163 people, 11,977 numbers of households with a population density of 26 inhabitants per $\mathrm{km}^{2}$ against 78 per $\mathrm{km}^{2}$ of Bikaner District. Paralleling the rise in human population, there was corresponding rise in livestock population by $1520 \%$, as well as an expansion of croplands (i.e., from $47.17 \%$ in $2005-06$ to $67.43 \%$ in $2015-16$ ), while the extent of grazing lands dropped from 1.70 to $1.62 \%$ during the same period.

In this study, annual rainfall data of the study area (Bikaner District) are collected for a period of 20 years (2000-2019) from website of Water Resources Department of Rajasthan (https://water.rajasthan.gov.in). This study utilized satellite imageries from Indian Remote Sensing (IRS) Resourcesat-1, Linear Imaging Self-Scanning (LISS-IV) satellite images of $5.8 \mathrm{~m}$ spatial resolution (two imageries), IRS-LISS III images of $30 \mathrm{~m}$ spatial resolution (one imagery), Sentinel 2A optical image (10 m spatial resolution) of ESA (European Space Agency) and Google Earth Images. The IRS images were purchased under projects while the Sentinel 2A imageries (date) were downloaded from the website (https://earthdata.nasa.gov/earth-observation). Moreover, data related to crop statistics such as cropped areas, yields and productivity of the major crops in the study area were downloaded for 2007-08 and 2017-18 from website of Department of Agriculture, Government of Rajasthan (https://agriculture.rajasthan.gov.in/).

\section{MATERIALS AND METHODS}

\subsection{Analyzing Rainfall Variability}

Basic statistical properties such as mean, standard deviation, coefficient of variation, skewness and kurtosis of annual rainfall data are computed. Bar charts of annual rainfall data for the period 2000-2019 are plotted to visualize the rainfall variability and a linear trend is fitted. A box-whisker plot of the annual rainfall is also plotted to depict five important properties of rainfall time series, i.e., minimum, maximum, $25^{\text {th }}$ and $75^{\text {th }}$ percentiles, and outliers/extremes (Machiwal and Jha, 2012). 


\subsection{Identification and Mapping of Diggi structures in Geographic Information System}

In this study, diggi structures are identified and delineated in geographic information system (GIS) using the satellite images of the years 2004 (from IRS-LISS 4) and 2018 (Sentinel-2A). These micro field-water storage structures are clearly visible in the remote sensing satellite (optical) imagery having very high spatial resolutions of 5.8 and $10 \mathrm{~m}$, for IRS-LISS 4 and Sentinel-2A, respectively and is verified from Google Earth Images (Figs. 3 and 4). These satellite images ease the process of identification and mapping of diggis due to their high spatial resolution of $10 \mathrm{~m}$, and thus, diggi features comfortably visible on the imageries are precisely mapped on the GIS platform. Three features of diggis that helped in their quick identification are (i) size of diggi structures, (ii) their shape (circular or rectangular), and (iii) their topological association with canals and croplands. Once identified, diggi structures are mapped through on-screen digitization from false color composites (FCCs) of satellite images for the years 2004 and 2018 using ArcGIS software (10.5). Locations of the delineated diggi structures are verified from the Google earth images.

\subsection{Mapping of Land Use/Land Cover}

Land use/land cover (LULC) maps of the study area are developed for two years, 2004 and 2018, using satellite imageries of IRS Resourcesat-1, LISS-III, and Sentinal-2A, respectively. The objectives of preparing these maps are to understand the spatial distribution pattern of irrigated croplands around the farm pond structures and to observe distribution of other types of LULC in the area. For LULC mapping, we used the national land use/land cover classification system developed by the National Remote Sensing Centre, Hyderabad (NRSC, 2010). As per this classification system, there are five Level I classes, eleven Level II classes, and fifteen Level III classes. It is worth mentioning that LISS III were used for mapping land use/land cover classes while for mapping the diggi structures, IRS-LISS IV and Sentinel-2A have been used. Supervised classification system followed by manual modification techniques were used for classifying the land use/land cover types.

\subsection{Cause-Effect Analysis of Diggi Structures with Changing Rainfall and Agricultural Statistics}

In arid climate of the study area, water remains available in scanty quantities for agriculture and allied sectors. Perhaps, this is the reason that rainwater harvesting is generally not considered as a dependable source of water supplies in the arid regions. Hence, motivation behind construction of diggi structures in the area is explored by examining gradual trend in rainfall series by applying Mann-Kendall test (Mann, 1945, Kendall, 1975), which is a nonparametric statistical test that is widely used for testing trends in hydrological studies. In this study, trends and pattern of rainfall are analyzed to identify whether the region received any major rainfall events during the study period. If rainfall quantities are found increasing then it would help in investigating whether increase in crop area, if any, also reflects the contribute of rainfall. Details of Mann-Kendall test are available in literature and may be found in 
Machiwal and Jha (2012). In addition, t-test is employed to evaluate abrupt changes in the mean of the annual rainfall over the years.

\subsubsection{Exploring Changes in Mean Rainfall by Applying t-test}

The parametric t-test is used to examine whether change in the mean annual rainfall between the first (2000-2009) and second (2010-2019) halves of the total 20-year series is statistically significant or not. It considers that the annual rainfall series is uncorrelated and normally distributed with mean $\mu$ and standard deviation $\sigma$. To apply the test, the whole rainfall series $\mathrm{x}_{\mathrm{t}}(\mathrm{t}=1,2, \ldots, \mathrm{n})$ is first divided into two subseries: (i) first subseries $\mathrm{x}_{\mathrm{i}}\left(\mathrm{i}=1,2, \ldots, \mathrm{n}_{1}\right)$ of size $\mathrm{n}_{1}$ has a mean $\mu_{1}$, and standard deviation $\sigma$, and (ii) second subseries $\mathrm{x}_{\mathrm{j}}\left(\mathrm{j}=\mathrm{n}_{1}+1, \mathrm{n}_{1}+2\right.$, $\ldots, \mathrm{n}$ ) of size $\mathrm{n}_{2}$ has a mean $\mu_{2}$ and standard deviation $\sigma$ such that $\mathrm{n}=\mathrm{n}_{1}+\mathrm{n}_{2}$. The test-statistic is defined as (Snedecor and Cochran, 1980):

$$
\begin{gathered}
\mathrm{ts}=\frac{\left|\overline{\mathrm{x}}_{2}-\overline{\mathrm{x}}_{1}\right|}{\mathrm{S} \sqrt{\frac{1}{\mathrm{n}_{1}}+\frac{1}{\mathrm{n}_{2}}}} \\
\text { and } \mathrm{S}=\sqrt{\frac{\left(\mathrm{n}_{1}-1\right) \mathrm{s}_{1}^{2}+\left(\mathrm{n}_{2}-1\right) \mathrm{s}_{2}^{2}}{\mathrm{n}-2}}
\end{gathered}
$$

where, $\bar{x}_{1}, \bar{x}_{2}, s_{1}^{2}$ and $s_{2}^{2}$ are the estimated values of the means and variances of the first and the second subseries, respectively. If the computed value of the test-statistic is greater than its critical value (at $n-2$ degrees of freedom and 5\% level of significance), then the null hypothesis that the mean of two subseries belong to the same population is rejected.

\subsubsection{Evaluating Impact of Diggis on Changes in Land Use/Land Cover}

Furthermore, impact of diggi structures on agriculture in the area is assessed by computing LULC changes over a period of 14 years (2004-2018) by differencing LULC maps of the years 2004 and 2018. Moreover, crop statistics, i.e., cropped areas, production and yield, of the major crops are comparatively evaluated over the two years, i.e., 2007-08 and 2017-18.

\section{RESULTS AND DISCUSSION}

\subsection{Temporal Characteristics of Rainfall}

The 20-year mean annual rainfall in the study area is found to be $240 \mathrm{~mm}$ with value of standard deviation as $104 \mathrm{~mm}$, which indicates that the area is rainfall deficit or drought prone. Value of the coefficient of variation for the annual rainfall is $43 \%$, which suggests that the annual rainfall is highly variable in the area. Positive value of skewness $(0.52)$ indicates that rainfall distribution is skewed to the right and close to zero. Likewise, positive value of kurtosis (1.13) indicates that the data distribution of annual rainfall is heavy-tailed with a 
sharper peak in comparison to the normal distribution curve. Similar findings are reported for semi-arid regions of Rajasthan and Gujarat (Machiwal and Jha, 2017; Machiwal et al., 2021).

Rainfall is considered as the most important deciding factor for agricultural planning in desert region. Bar charts of the annual rainfall in the study area showed occurrence of a few good rainfall totals ranging from 300 to $500 \mathrm{~mm}$ during three years, i.e., 2005, 2008, 2015 and also very low annual totals of $34 \mathrm{~mm}$ during severe drought in 2002 and about $150 \mathrm{~mm}$ during 2004 and 2009 (Fig. 5a). The fitted linear regression line depicts an increasing trend with a magnitude of $4.62 \mathrm{~mm} \mathrm{year}^{-1}$ in the annual rainfall. However, the linear regression trend is not perfectly fitted as the value of coefficient of determination $\left(\mathrm{R}^{2}=0.07\right)$ is close to zero (Fig. 5a). Box-whisker plot of the annual rainfall is shown in Fig. 5b, which reveals that the median value of the annual rainfall is $232 \mathrm{~mm}$ in the area. It is further seen that the median value of the rainfall is not exactly at the center of the box and lengths of the upper and lower whiskers are also not perfectly equal to each other. This suggests that the rainfall distribution is slightly non-uniform, which is further confirmed with presence of one outlier on the upper side that makes the distribution skewed to the right. This finding is in agreement with that obtained from the skewness value. Hence, annual rainfall has large variations but shows no significant increase in the area over the past 20 years.

\subsection{Spatial Mapping and Changes in Distribution of Diggis}

The diggi structures digitized on-screen using satellite images of two time periods, 2004 and 2018 are shown in Figs. 6 and 7. Mapping of diggis revealed that compared to the year 2004, there appears a greater number of diggis during 2018 and higher density of diggis was found in the central, north and northwest parts of tehsil mostly in Kheersar, Poogal, Karanpura and Ramai villages. A comparison of statistics for two diggi features, i.e., number of diggis and area occupied by diggis, for the two time periods reveals that diggi structures increased by 13 times from 241 during the year 2004 to 3162 numbers during the year 2018 (Table 1). Likewise, there is three times increase in total cumulative area covered by diggi from 85.94 ha during the year 2004 to 324 ha in the year 2018. Locations of all the identified and mapped diggis are verified by visually comparing satellite imageries with the Google Earth images.

Rainfall pattern in the study area over two decades (2000-2019) depicted at least five droughts including the worst drought of 2002, which was the severest not only in Rajasthan but also in history of India having its impact on $56 \%$ of the geographical area and the livelihoods of 300 million people in 18 states (Samra, 2004). Under such conditions, farmers of this region, could harvest a single annual crop of pearl millet. However, much of the problems of water requirement have been solved due to IGNP canal system. This is the only available source of assured water supplies to meet the water demands of people living in the extreme arid districts of Bikaner, Jaisalmer and Barmer. With time, farmers of this region have availed the benefit of canal water and as an impact, some important transformations 
have been taken place in agricultural sector such as (i) many of the areas having low to medium sand dunes have been levelled for cropping, (ii) mono-crop areas have changed to double cropping, (iii) farmers are now cultivating highly water-intensive crops (from traditional cereal crops to more profitable horticulture crops), and (iv) there is a shift from traditional rainfed systems to irrigated agriculture. All these activities require additional water, thus prompts people to think alternate ways like diggi system to store their quota of allocated water of Indira Gandhi canal. Water is transferred to diggis to be used later on as per requirement (Goyal et al., 2019). Farmers pump out water from diggi using electric motor and then apply to field by micro-irrigation devices such as sprinklers and drip systems. The Government too has recognized the importance of diggi in these areas and came out with a standard design of diggi $(110$ feet $\times 110$ feet $\times 10$ feet size with 18 feet side slope $)$ to store about 25 lakh liters of water. Farmers have also prepared a system connecting the diggis with photo-voltaic solar panels to run electric pump for operating sprinkler and drip systems (Tewari, 2012). Government of Rajasthan is also providing 50\% subsidy for constructing the diggis (Amarasinghe et al., 2008). To reduce the construction cost, these diggis are lined with high-density polyethylene (HDPE) sheets of 300 to 500 micron thickness. It is understood from the above discussion that requirement of additional water to meet irrigation requirements timely and provision of getting subsidy led to remarkable growth of number of diggis in the area.

\subsection{Land Use/Land Cover Maps}

Nine classes of land use/land cover (LULC) units are identified and mapped in the study area. The LULC maps for the years 2004 and 2018 are shown in Figs. 8 and 9. In the year 2004, it is seen that sandy/dune LULC class dominate in the area encompassing 184924 ha $(70.68 \%)$ area followed by fallow lands (33851.60 ha, 12.94\%) and area under irrigated agriculture (25660.10 ha, $9.81 \%$ ). These three LULC classes cover $93.43 \%$ of total study area in the year 2004. Similarly, in the year 2018, sandy/dune LULC class covers 169938 ha $(64.96 \%)$ of the study area followed by irrigated agriculture (46221.30 ha, 17.67\%) and fallow lands (16012 ha, 6.12\%), and hence, these three classes have a spread over $88.75 \%$ lands. Agricultural lands including irrigated croplands, un-irrigated croplands and fallow lands constituted 25\% of the study area in the year 2004, which got increased up to $29.02 \%$ in the year 2018 . These results indicated significant increase in total crop area and majority of such lands were irrigated types.

\subsection{Interactions among Rainfall-Diggis-Agricultural Statistics}

The calculated test-statistic ( $\mathrm{z}$ ) value of the Mann-Kendall test is obtained as +0.91 ( $\mathrm{p}$ value $=0.36$ ), which indicates a positive trend in annual rainfall series of the study area. However, as the calculated $z$-value is less than its critical value $(+1.96)$, the increasing trend is not statistically significant at $5 \%$ level of significance ( $\mathrm{p}$-value $>0.05$ ). It is further observed from Sen's slope estimation test that magnitude of the non-significant increasing trend is 3

mm year ${ }^{-1}$. The value of ts-statistic of t-test is computed to be 1.38 , which is less than its 
critical value (1.73) at 5\% level of significance but more than the critical value (1.33) at $10 \%$ level of significance. Hence, it is statistically evident that the rainfall means during two 10year periods, i.e., 2000-2009 and 2010-2019 are significantly different (p-value<0.10). Also, as the mean annual rainfall for the period 2010-2019 $(271 \mathrm{~mm})$ is higher than the mean annual rainfall for the 2000-2009 period (208 mm), it is apparent that the amount of annual rainfall has been increasing over the recent years in the area. This shift in the mean annual rainfall is depicted in Fig. 5. Similar findings of increasing rainfall quantities in arid regions of Rajasthan and Gujarat are reported in the literature (e.g., Kharol et al., 2013; Machiwal et al., 2016; Meena et al., 2018; Machiwal et al., 2019). The rising amount of annual rainy events in the Indian arid regions over the last one or two decades augmented the surface water availability in canals. The rising rainfall quantities have played a significant role in large increase in number of diggis in the entire western arid region of the country that stores surplus quantities of canal water at times of their availability, and the same is used later to timely irrigate the crops. A few farmers in the area have been adopting the high-yielding crop varieties in order to enhance the crop production as well as productivity.

Since the sole objective of diggi based water management is to provide timely irrigation to crops, the change in LULC of the study area is also detected over the same period, i.e., from 2004 to 2018. The LULC changes have been analyzed by preparing a matrix. The table shows change detection matrix list land-cover classes of 2018 image in the columns and land cover classes of 2004 image in the rows (Table 5). Based on this matrix, it is shown that mainly large sand dune areas have been converted to plantations/shelterbelts (20843.8 ha) and agricultural use (8681.83 ha) from 2004 to 2018. Parts of scrublands (2120.95 ha) have been converted to agriculture under irrigated types. Fallow lands have decreased and are now converted to agriculture (10432.65 ha). Parts of irrigated croplands are now utilized under plantations and shelterbelts.

It is learnt from the rainfall in the study area has been fairly increasing; through there have been drought years. Thus, increase in crop area mainly under irrigated lands is due to expansion in croplands facilitated with timely utilization of stored canal water through diggis and slightly increasing rainfall that have enhanced the canal water potential in the area. The area under sand dunes in the area has also decreased by $5.72 \%$. Because of the storage water in diggis, people have also stopped earlier practice of land fallowing. Thus, fallow land areas have decreased by $6.82 \%$. Similar findings have been reported in earlier studies (Kar, 2014). It was also found that most of the new irrigated croplands were diggi centric. Major kharif crops of this region are pearl millet, moth bean, cluster bean and sesame under rainfed conditions and groundnut, cotton, and wheat under irrigated conditions. During winter season, chickpea, mustard and wheat are grown as the major crops. A ccomparative data for a decadal change in crop area, crop production and yield for 2007-08 and 2017-18 in Bikaner district has been shown in Table 3. The results showed a significant increase in crop area and irrigated area under each crop from the minimum of $17 \%$ increase in case of cluster bean to the maximum of $330 \%$ increase in case of groundnut. For example, area under green gram 
crop increased from 2535 ha during 2007-08 to 53449 ha. Similarly, there has been significant increase in area under cereals, food grains and oilseeds from 2007-08 to 2017-18 (Table 4). The total production and higher yield of crops are also achieved, which are due to important contributions of management factors like timely application of water at different crop growth stages.

\section{CONCLUSIONS}

Diggi is an indigenous micro-hydrological structure that has become a quite popular strategy for water management at field scale in the canal command area of desert districts in Rajasthan, India. Satellite image based interpretations of study area indicated significant increase of 13 times in the number of diggi structures between 2004-05 and 2018, thus, indicating people's requirement and magnificent adoption of such structures by farming community within the command area of IGNP. It is apparently seen that rainfall has been fairly rising in the arid lands of the Great Indian Desert, which have positive implications in improving potential availability of canal water in this region. As an impact, local farmers are now able to follow crop calendar, to decide irrigation schedule and decide upon choice of cropping pattern. The perpetual problems of erratic and limited electricity supply and disruption in irrigation activities has also been minimized. Farmers are able to expand their irrigated crop area. The change detection matrix for two periods indicated large areas under sand dunes, scrublands and fallow lands have been converted to agriculture. The water use efficiency has also improved by bringing additional area under cropping due to water saved by sprinkler or drip system in comparison to flood irrigation. However, study also found few limitations of this system; the water in diggis is also prone to evaporation losses under high desertic conditions. Farmers will have to judiciously and timely utilize the stored water; otherwise, failure and negligence will incur huge loss of precious water. It is also suggested that effort should be made to increase vegetation around diggi that will improve the microclimate, reduce ambient temperature, cause less evaporation losses and also reduce siltation of canals.

\section{Acknowledgements}

Authors are grateful to the Director, ICAR-Central Arid Zone Research Institute, Jodhpur, India for providing necessary facilities to carry out this research work in the laboratory and during field survey. The technical help provided by staffs of the institute during the field survey is also acknowledged.

\section{References}

Amarasinghe, U.A., Bhaduri, A., Singh, O.P., Ojha, A. and Anand, B.K. (2008). Cost and benefits of intermediate water storage structures: Case study of diggies in Rajasthan. In: Kumar, M.D. (Editor), Managing Water in the Face of Growing Scarcity, Inequity and Declining Returns: Exploring Fresh Approaches. Proceedings of the $7^{\text {th }}$ Annual Partners Meet, IWMI TATA Water Policy Research Program, ICRISAT, Patancheru, Hyderabad, India, 2-4 April 2008. Vol. 1. Hyderabad, India: International Water Management Institute (IWMI), South Asia Sub Regional Office. pp. 51-66. 
Bhat, T.A. (2014). An analysis of water demand and supply in India. Journal of Environment and Earth Science, 4(11): 67-72.

Goyal, R.K. and Vittal, K.P.R. (2008). Water resources management in hot arid zone of India, Journal of Hydrological Research and Development, 23: 37-54.

Goyal, R.K., Angchok, D., Stobdan, T., Singh, S.B. and Kumar, H. (2009). Surface and Groundwater Resources of Arid Zone of India: Assessment and Management. In: Amal Kar, B.K. Garg, M.P. Singh and S. Kathju (Editors),Trends in Arid Zone Research in India, Central Arid Zone Research Institute, Jodhpur, pp. 113-150.

Goyal, R.K., Singh, J.P. and Gaur, M.K. (2018). Khadin system of runoff farming for crop production. Indian Farming, 68(09): 26-28.

Goyal, R.K., Moharana, P.C. and Gaur, M.K. (2019). Diggies-micro conservation structures in desert region of Rajasthan. CAZRI News, 9(2) April-June, 2019. pp. 5-6.

Hussain, J., Husain, I. and Arif, M. (2014). Water resources management: traditional technology and communities as part of the solution. In:Evolving Water Resources Systems: Understanding, Predicting and Managing Water-Society Interactions, Proceedings of ICWRS2014, Bologna, Italy, June 2014 (IAHS Publ. 364, 2014), pp. 236-242. DOI:10.5194/piahs-364-236-2014.

Kar, A. (2014). Agricultural land use in arid Western Rajasthan: Resource exploitation and emerging issues, Agropedology, 24(02): 179-196.

Kendall, M.G. (1975). Rank Correlation Methods. Charles Griffin and Co. Ltd., London, U.K.

Kharol, S.K., Kaskaoutis, D.G., Badarinath, K.V.S., Sharma, A.R. and Singh, R.P. (2013). Influence of land use/land cover (LULC) changes on atmospheric dynamics over the arid region of Rajasthan state, India. Journal of Arid Environments, 88: 90-101.

Machiwal, D. and Jha, M.K. (2012). Hydrologic Time Series Analysis: Theory and Practice. Springer, Germany and Capital Publishing Company, New Delhi, India, 303 pp.

Machiwal, D. and Jha, M.K. (2017). Evaluating persistence, and identifying trends and abrupt changes in monthly and annual rainfalls of a semi-arid region in western India. Theoretical and Applied Climatology, 128(3-4): 689-708.

Machiwal, D., Gupta, A., Jha, M.K. and Kamble, T. (2019). Analysis of trend in temperature and rainfall time series of an Indian arid region: Comparative evaluation of salient techniques. Theoretical and Applied Climatology, 136(1-2): 301-320.

Machiwal, D., Kumar, S. and Dayal, D. (2016). Characterizing rainfall of hot arid region by using time series modeling and sustainability approaches: A case study from Gujarat, India. Theoretical and Applied Climatology, 124: 593-607.

Machiwal, D., Parmar, B.S., Kumar, S., Meena, H.M. and Deora, B.S. (2021). Evaluating homogeneity of monsoon rainfall in Saraswati river basin of Gujarat, India. Journal of Earth System Science, in press.

Mann, H.B. (1945). Non-parametric tests against trend. Econometrica, 13: 245-259.

Meena, H.M., Machiwal, D., Santra, P., Moharana, P.C. and Singh, D.V. (2019). Trends and homogeneity of monthly, seasonal and annual rainfall over arid region of Rajasthan, India. Theoretical and Applied Climatology, 136: 795-811. https://doi.org/10.1007/s00704-018-2510-9.

Kumar, S., Ramilan, T., Ramarao, C.A., Srinivasa Rao, C. and Whitbread, A. (2016) Farm level rainwater harvesting across different agro climatic region of India: Assessing performance and its determinants. Agricultural Water Management 176, 55-66.

Moharana, P.C., Gaur, M.K., Choudhary, C., Chauhan, J.S. and Rajpurohit, R.S. (2013). A system of geomorphological mapping for western Rajasthan with relevance for agricultural land use. Annals of Arid Zone, 52(3\&4): 163-18. 
Narain, P. and Khan, M. A. (2000). Water resources development and utilization for drinking and plant management in Indian arid regions. In: Advances in Land Resources Management for $21^{\text {st }}$ Century. International Conference on Land Resources Management for Food, Employment and Environmental Security. Proceedings. New Delhi, India: Soil Conservation Society of India, pp. 404414.

Samra, J.S. (2004). Review and analysis of drought monitoring. Declaration and Management in India. Working Paper 84, International Water Management Institute (IWMI), Colombo, Sri Lanka, 31.

Sharma, B.R., Rao, K.V.G.K and Sharma, G. (2010). Groundwater Externalities of Large Surface Irrigation Transfers: Lessons from Indira Gandhi Nahar Pariyojana, Rajasthan. International Water Management Institute, New Delhi. pp.107-121,https://publications.iwmi.org/pdf/H042689.pdf.

Shrivastava, M., Sharma, I.K. and Sharma, D.D. (2013). Ground Water Scenario in Indira Gandhi Nahar Pariyojna (IGNP) in parts of Sri Ganganagar, Hanumangarh, Churu, Bikaner, Jaisalmer, Jodhpur and Barmer Districts, Rajasthan. In: Memoir Geological Society of India, No. 82, pp. 16-35.

Snedecor, G.W. and Cochran, W.G. (1980). Statistical Methods. Iowa State University Press, Ames, Iowa.

Tewari, N.P. (2012). Solar Irrigation Pumps: The Rajasthan Experience. Water Policy Research Highlight-35, IWMI Tata Water Policy Program, International Water Management Institute, Colombo, Sri Lanka, p. 7.

UNESCO, UN-Water (2020). United Nations World Water Development Report 2020: Water and Climate Change, United Nations Educational, Scientific and Cultural Organization (UNESCO), Paris, p. 219. 
Figures

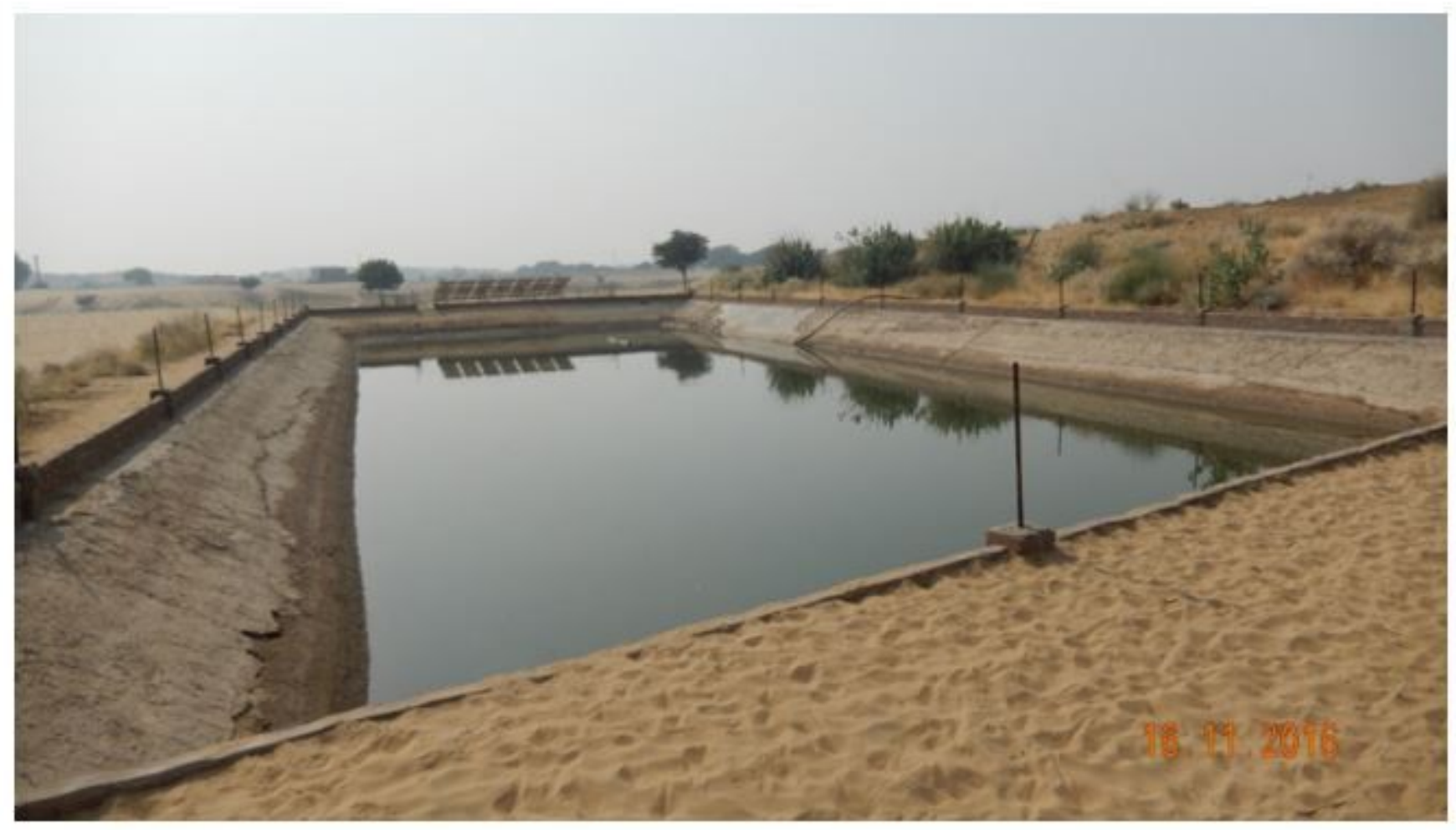

Figure 1

Field photograph of Diggi in the dune covered area in Poogal block of Bikaner, Rajasthan 


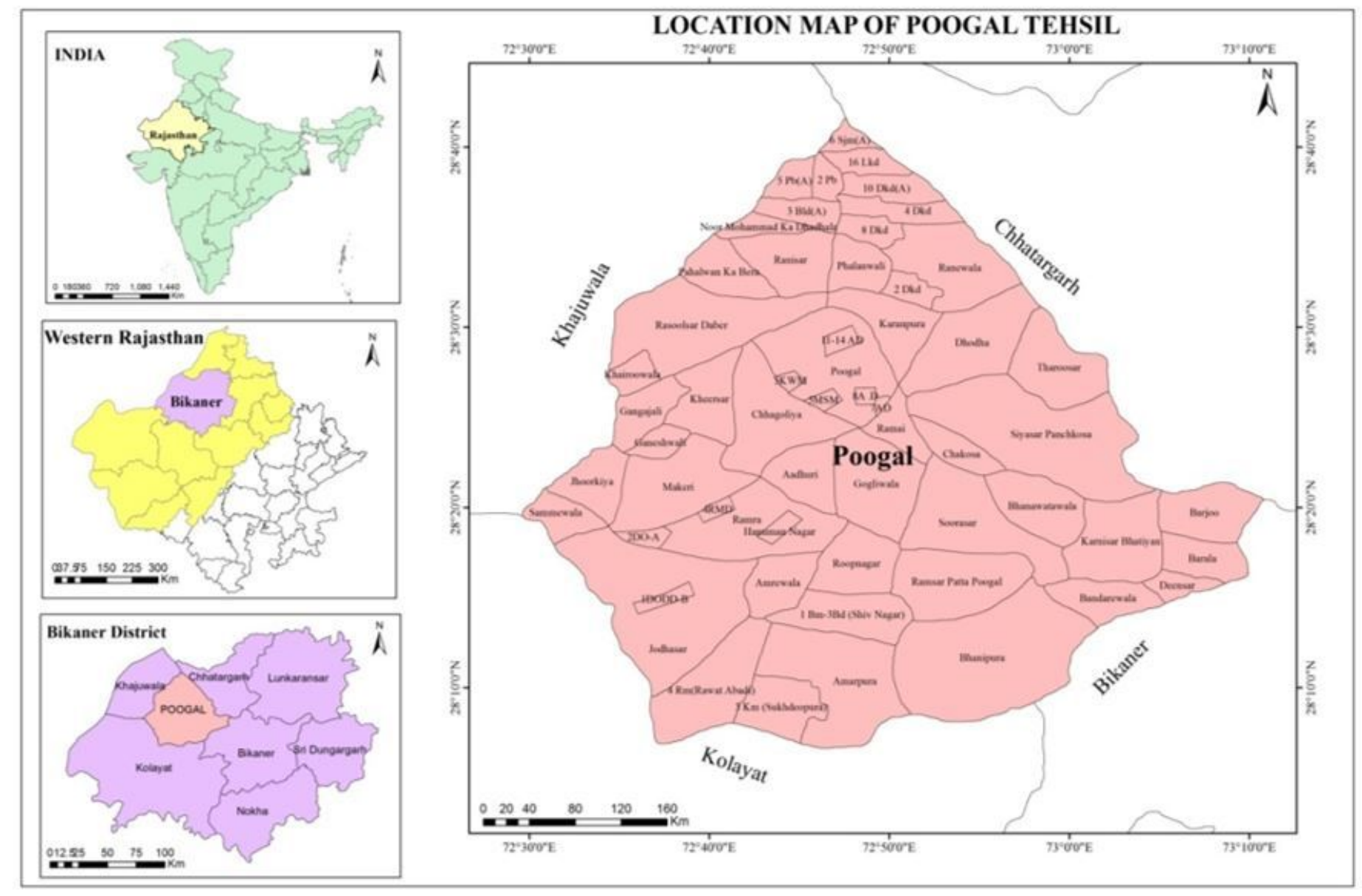

Figure 2

Location of study area Note: The designations employed and the presentation of the material on this map do not imply the expression of any opinion whatsoever on the part of Research Square concerning the legal status of any country, territory, city or area or of its authorities, or concerning the delimitation of its frontiers or boundaries. This map has been provided by the authors. 


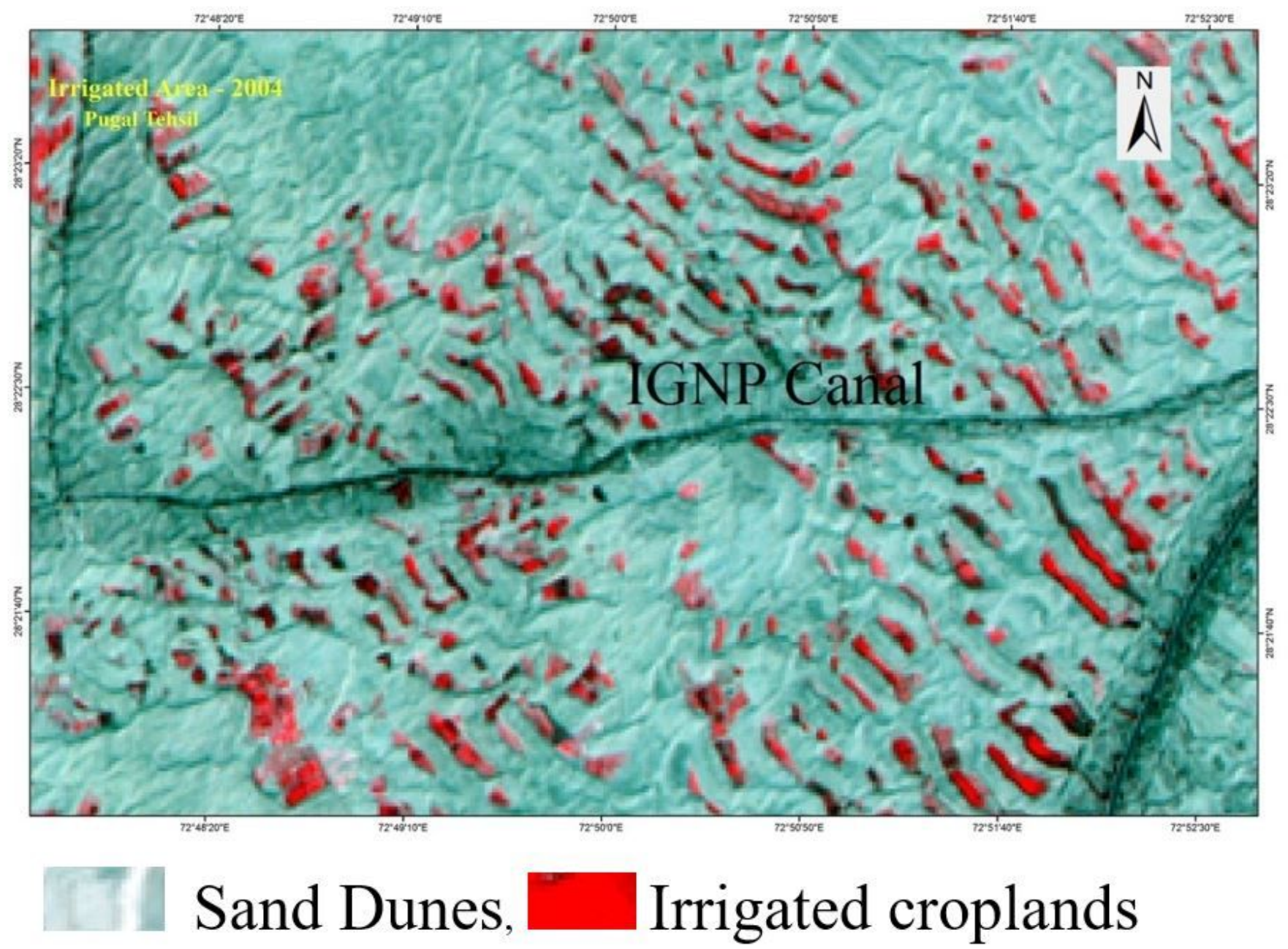

Figure 3

Diggi structures, irrigated crop area and sand dunes as viewed on satellite image (IRS-LISS III, 2004) of a part of study area. 


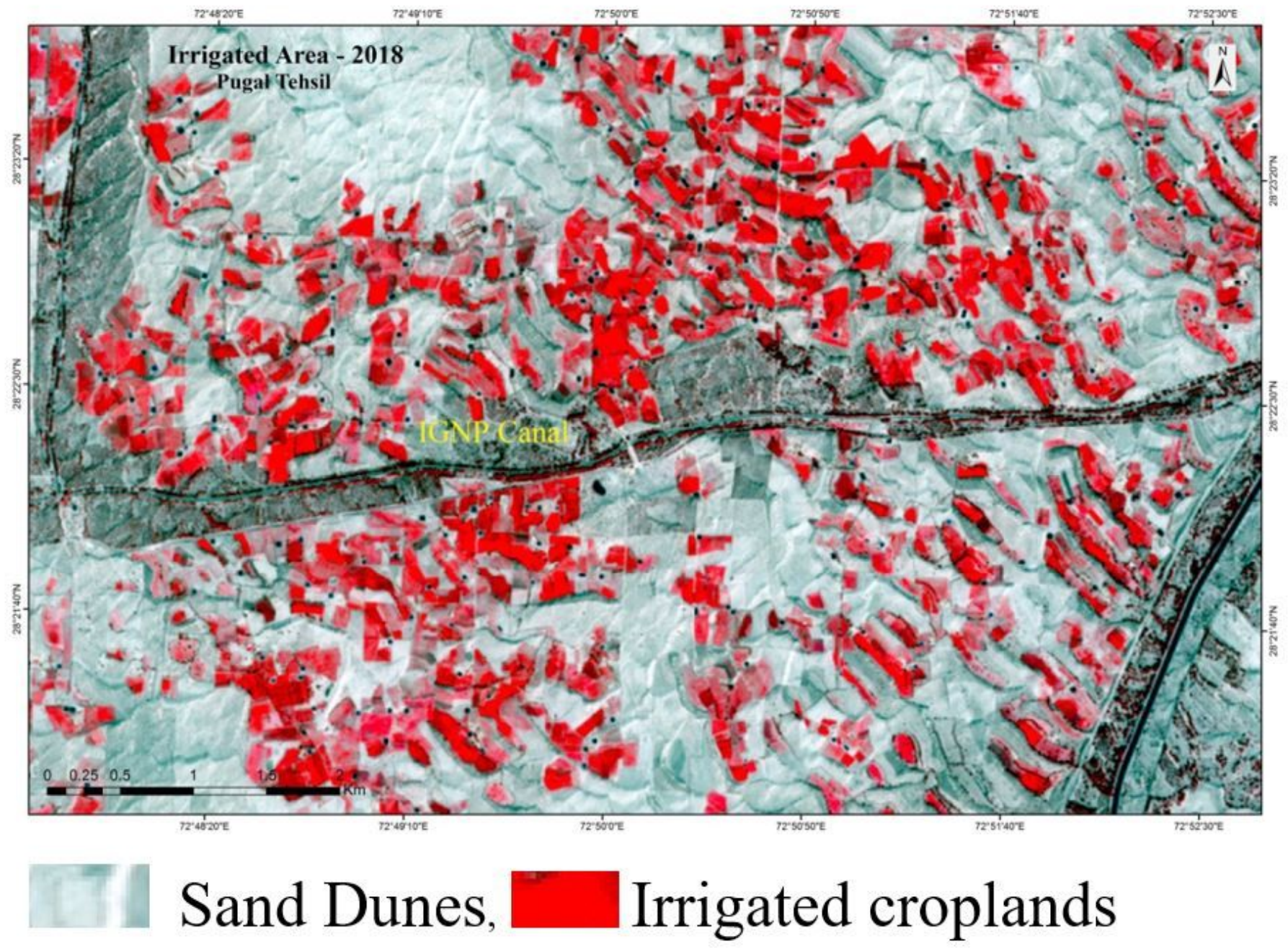

Figure 4

Diggi structures, irrigated crop area and sand dunes as viewed on satellite image (Sentinel, 2A, 2018) of a part of study area. 
(a)

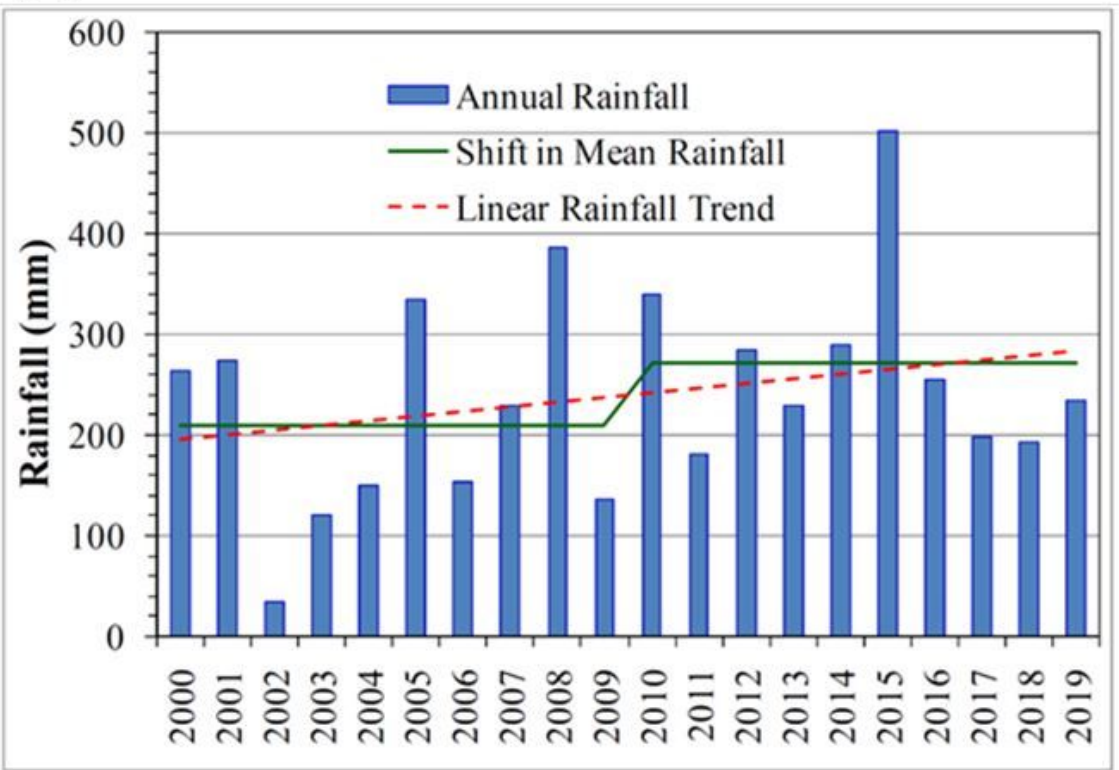

(b)

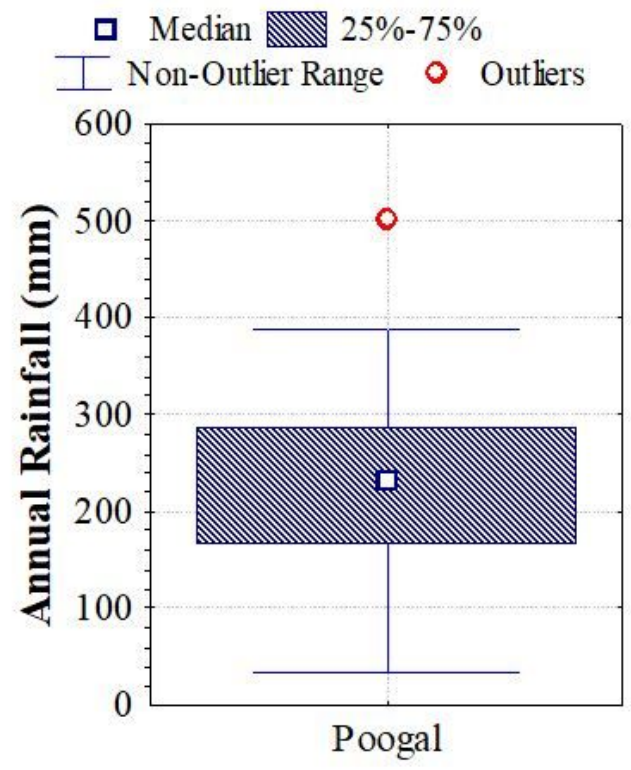

Figure 5

Bar charts of 20-year (2000-2019) annual rainfall showing a significant shift in the mean values after year 2010 


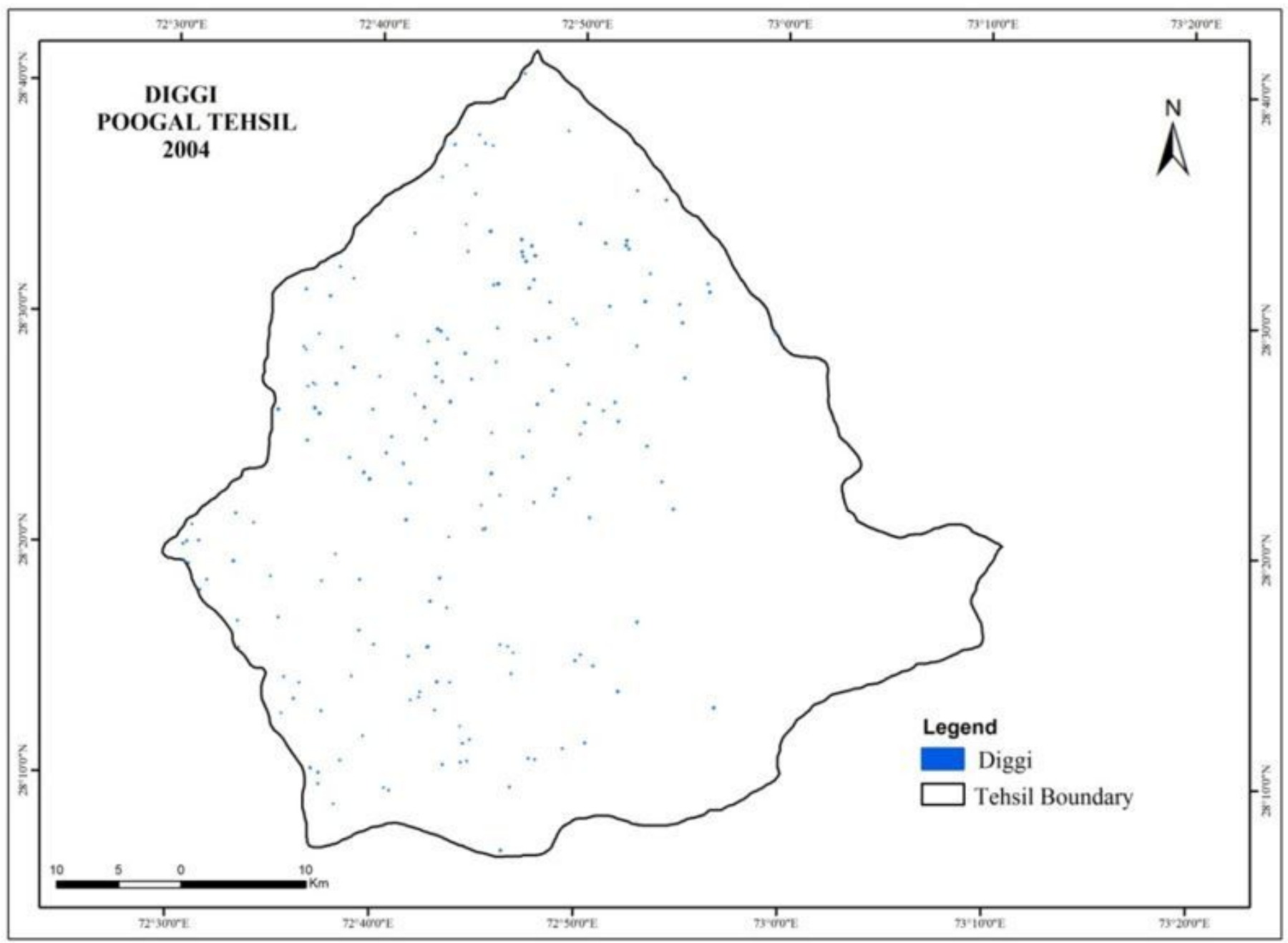

Figure 6

Spatially-distributed Diggi structures on map of the study area during the year 2004 Note: The designations employed and the presentation of the material on this map do not imply the expression of any opinion whatsoever on the part of Research Square concerning the legal status of any country, territory, city or area or of its authorities, or concerning the delimitation of its frontiers or boundaries. This map has been provided by the authors. 


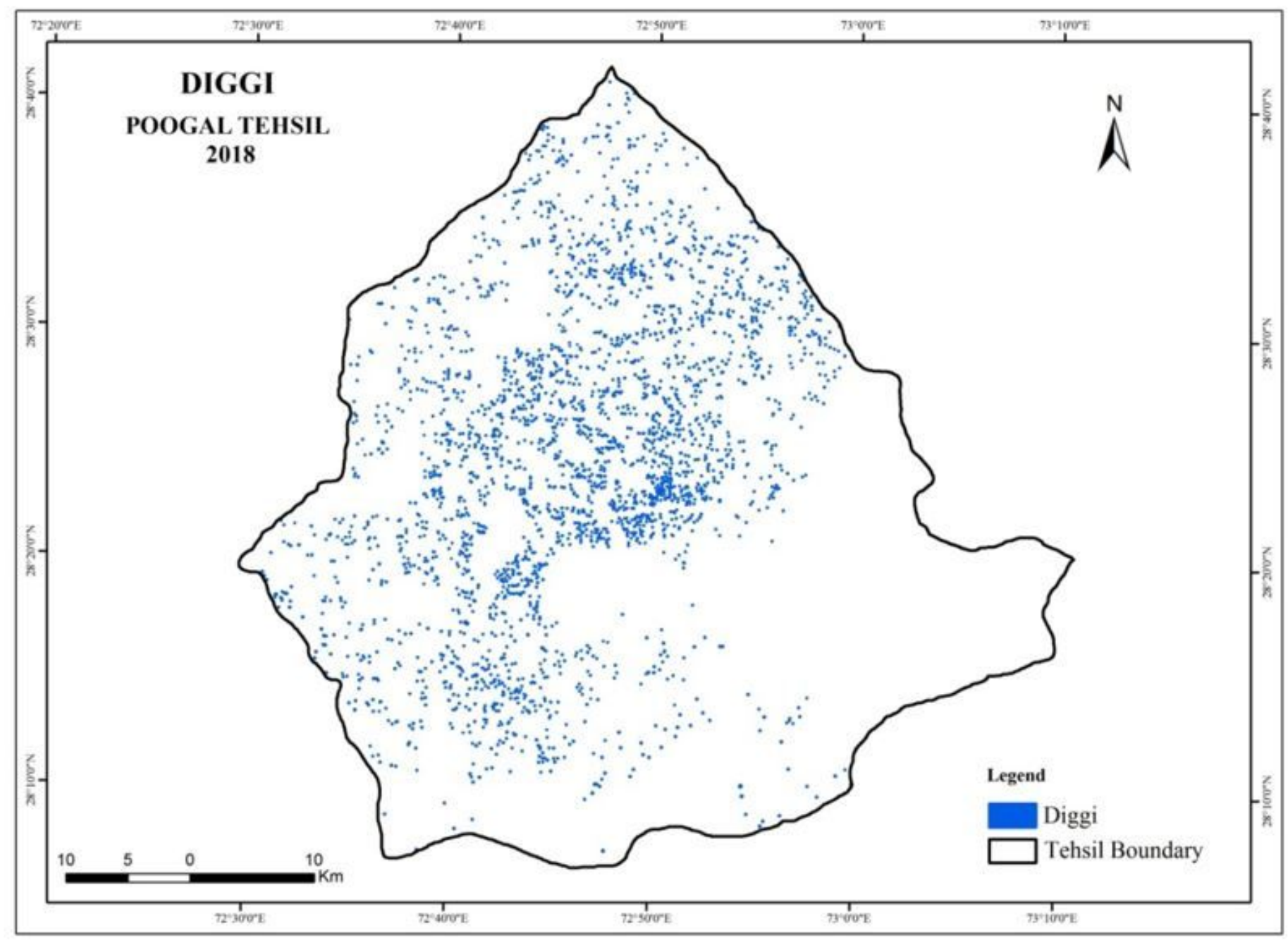

Figure 7

Spatially-distributed Diggi structures on map of the study area during the year 2018. Note: The designations employed and the presentation of the material on this map do not imply the expression of any opinion whatsoever on the part of Research Square concerning the legal status of any country, territory, city or area or of its authorities, or concerning the delimitation of its frontiers or boundaries. This map has been provided by the authors. 


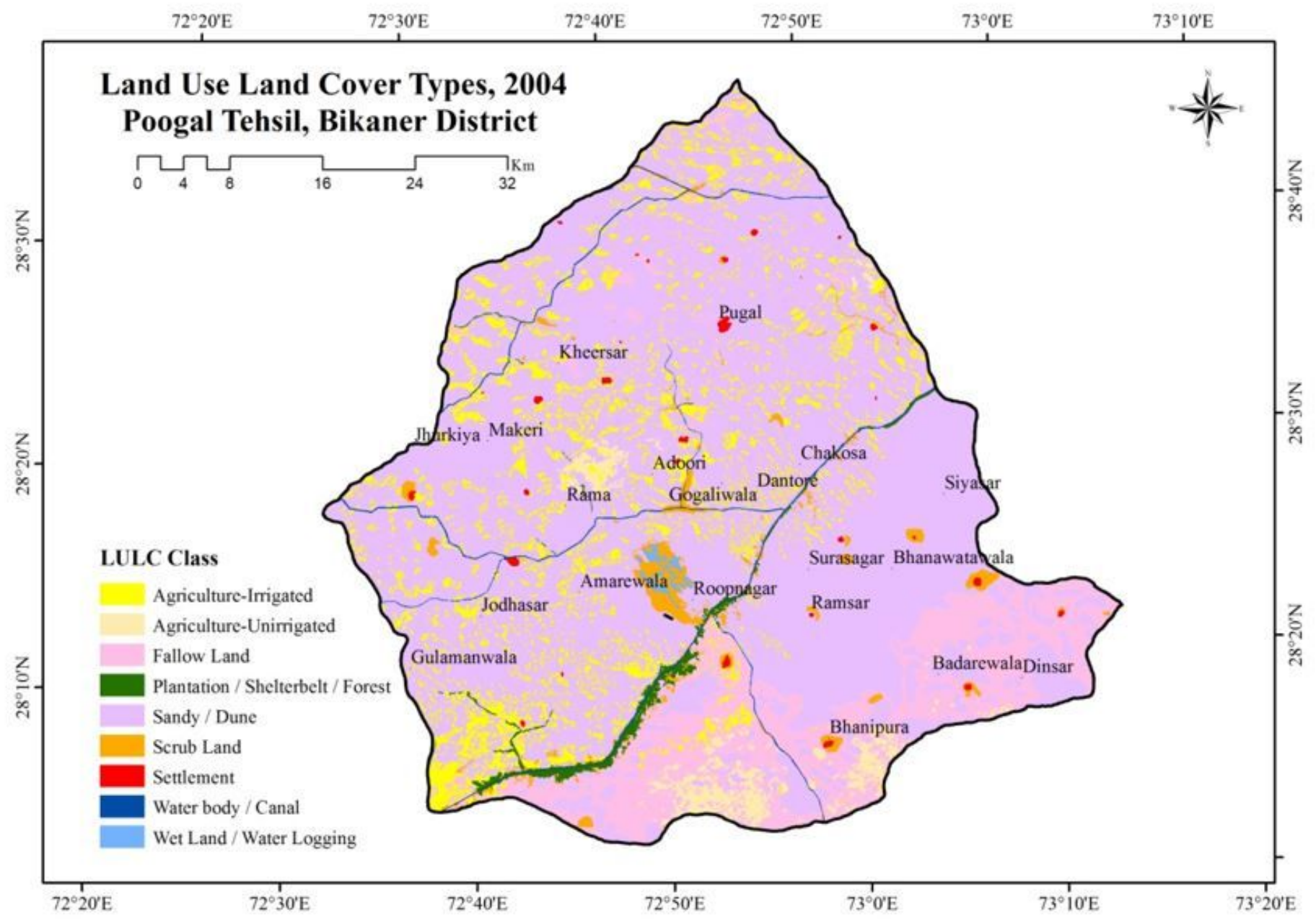

Figure 8

Land use/land cover map of the study area for the year 2004 Note: The designations employed and the presentation of the material on this map do not imply the expression of any opinion whatsoever on the part of Research Square concerning the legal status of any country, territory, city or area or of its authorities, or concerning the delimitation of its frontiers or boundaries. This map has been provided by the authors. 


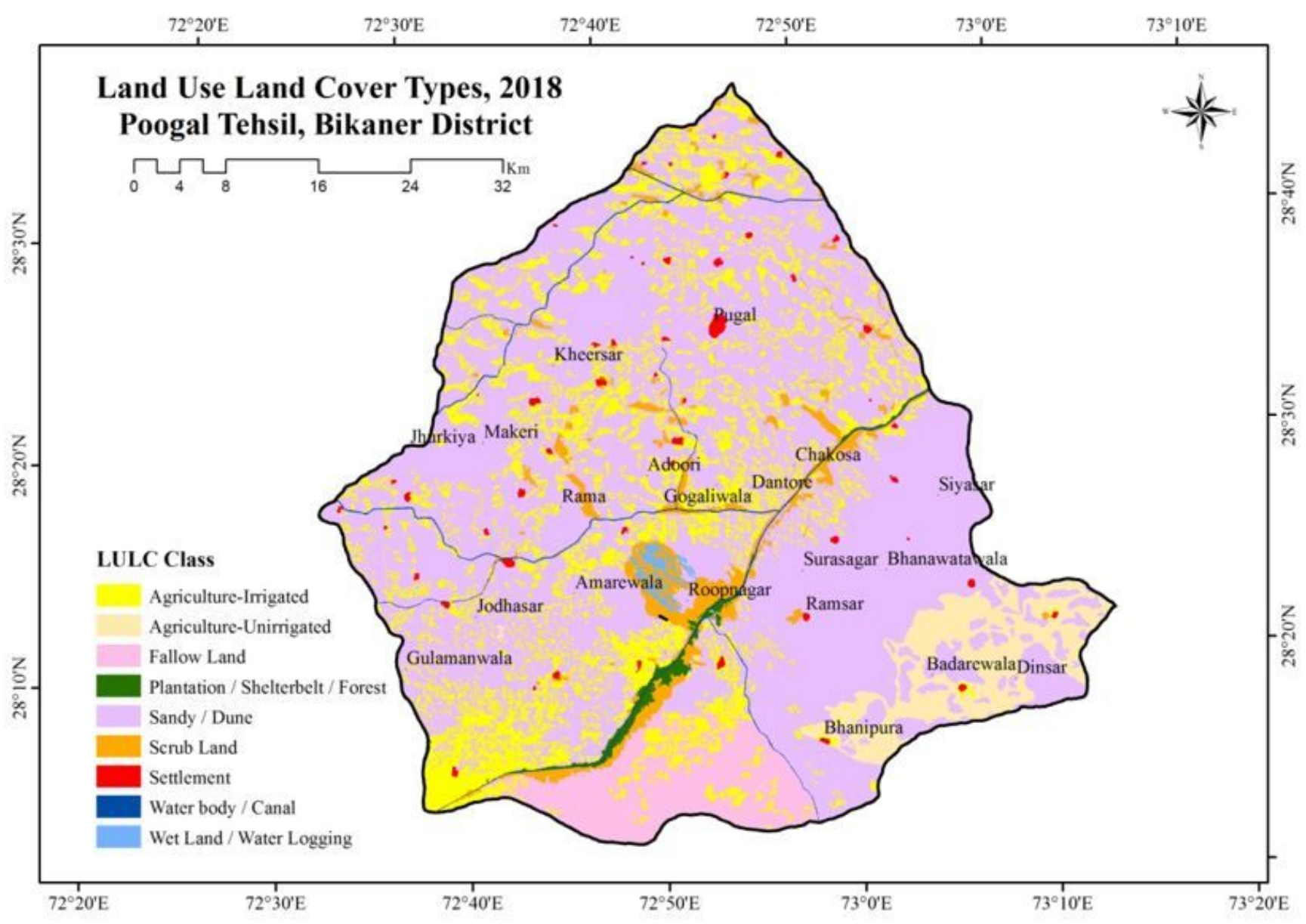

Figure 9

Land use/land cover map of the study area for the year 2018 Note: The designations employed and the presentation of the material on this map do not imply the expression of any opinion whatsoever on the part of Research Square concerning the legal status of any country, territory, city or area or of its authorities, or concerning the delimitation of its frontiers or boundaries. This map has been provided by the authors. 